\title{
GLOBALIZATION: DO AFRICAN WOMEN ENTREPRENEURS MATTER?
}

\author{
Elijah Bitange Ndemo ${ }^{1}$, Ben Mkalama ${ }^{2}$ \\ ${ }^{1}$ University of Nairobi, School of Business, Nairobi, Kenya
}

*Corresponding Author: Elijah Bitange Ndemo

Corresponding Author Email: bndemo@uonbi.ac.ke

Article Received: 11-04-19 Accepted: 29-04-19

Published: 05-05-19

Licensing Details: Author retains the right of this article. The article is distributed under the terms of the Creative Commons Attribution-NonCommercial 4.0 Licence (http://www.creativecommons.org/licences/by-nc/4.0/) which permits non-commercial use, reproduction and distribution of the work without further permission provided the original work is attributed as specified on the Journal open access page.

\begin{abstract}
Even with the increased number of women enterprises and efforts to help women entrepreneurs in Africa exploit the potential benefits globalization, gender inequalities (perception and treatment of women in Africa) still stand in their way. This paper seeks to address three questions: First, what the literature suggests with respect to re-thinking alternative analytical approaches to a new understanding of globalization, entrepreneurship and gender equality in global commerce. This will be followed by the question on how Africa conceptualizes women entrepreneurship and lastly, if the current African conceptualization of women entrepreneurs could precipitate exploitation of opportunities that the emerging global order presents. The literature suggests that women still have a long way to go in changing environmental forces and perceptions to fully exploit their potential in the global stage. A new theoretical way of analyzing their progress is imperative.
\end{abstract}

KeyWords: Entrepreneurship, Women entrepreneurs, Globalization

\section{INTRODUCTION}

In spite of increased favourable initiatives, policies and support programs to promote women entrepreneurship, gender disparities continue to undermine progress of women-led enterprises across the continent of Africa (Stark, 2003; Lindio-McGovern \& Wallman, 2016). Studies suggest that women entrepreneur participation in the global commerce is hindered from realizing their full potential by many factors (Osoro, Nyamongo, \& Areba, 2013; Vossenberg, 2013). These include: Legal, Financial, Education, how women Entrepreneurs are conceptualized, theoretical analytical methods and other environmental factors. Globalisation 
requires a collapse of borders and markets, leading to a merger of new products, way of doing things, communication, and ideas thereby allowing seamless communication and trade (Lucas, 2007). A broader analytical viewpoint cast in this paper explores the questions: Is it time to re-think alternative analytical approaches that could give rise to a new understanding of globalization, entrepreneurship and gender equality in global commerce? How is the concept of women entrepreneurship conceptualized in Africa? Can the current African conceptualization of women entrepreneurs lead to the exploitation of opportunities the emerging global order presents?

In this insight paper, we look beyond the usual statistics around the progress of women participation in globalization to review both theoretical and methodological (Freeman, 2001) approaches that have far greater impact than the superficial means of analytics used to report the progress women have made thus far. Further, the paper will explore the conceptualization of women entrepreneurs in Africa through the lenses of economic, organizational, political, social, and cultural environments which are critical to developing the full potential of women entrepreneurs. The paper will develop a framework to bring change on how women entrepreneurs are perceived by society as a mechanism for greater participation by women in the emerging world order. The objective of the paper is to provide a better understanding and provoke a discourse towards a new thinking toward the exploitation of the potential women can bring into global commerce - and highlight why some countries may or may not embrace new approaches to analyzing women entrepreneurs.

\section{Globalization, Entrepreneurship and Gender Equality}

As geographical barriers diminish (Ernest and Young, 2011) with the advent of Information and Communications Technologies (ICTs), globalization (the interaction and integration between organizations, governments, and people worldwide) is expanding, forcing small and big entrepreneurs to increasingly think global. Globalization, however, as (Subhalakshmi, 2012) argues, impacts women in different ways by helping them mobilize resources, encouraging treatment of women at the global stage and lowering gender inequality (perceptions or unequal treatment of persons either wholly or partly due to their gender). (Marchant, 2018) argues that because of rapid technological advancements, technological entrepreneurship is becoming a kind of "global community of practice" where there are standards and norms for those practices and there is pressure to scale businesses not only to the local levels, but also to the international level. While she talks about tech entrepreneurship specifically and not entrepreneurship more broadly, she illustrates how the globalizing forces create both opportunities and challenges for entrepreneurs.

The major debate on globalization, entrepreneurship and gender was brought to the fore through the World Development Report (World Bank, 2012) that raised two key dichotomous arguments on globalization and advancement of gender equality that remain relevant to date. The report argues that considering the fact that gender inequalities and discrimination persist in all parts of the world, globalization could affect women more negatively than men. Secondly, globalization could indeed lead to greater gender inequality, warning that it needed to be accompanied by public policy.

Luis Alfonso Dau and his coauthors show how international organizations can promote entrepreneurship opportunities for women, especially under the United Nations Global 
Agenda for Sustainable Development, as a strategy to empower women entrepreneurs through institutions that encourage women equality (Luis, Moore, \& Max, 2018).

(Ratten \& Tajeddini, 2018) noted that even though there was an increasing interest in the role of women entrepreneurship, very little research was conducted to develop its links with emerging international patterns. In their research, they discussed the role of women in entrepreneurship and internationalization through the lenses of three schools (philosophy, management and motivations) of thought around the subject in an attempt to build new theories that will enable new research into globalization and women entrepreneurship. There is increasing interest in the role of women in entrepreneurship, yet little research has been conducted about its link with internationalization patterns.

(Bahramitash \& Esfahani, 2014) argue that although female entrepreneurship has become a globally important topic in recent years, in the Middle East and North Africa (MENA) region, the topic remains under-researched despite the significance of female entrepreneurship as a means of addressing the disproportionately high unemployment level within the educated female work force. Their study results suggest that entrepreneurship rate among Iranian women falls within the regional variation and remains low relative to other regions of world outside Asia.

Further, (Bahramitash \& Esfahani, 2014) highlight some of the notable characteristics of female entrepreneurship, indicating a high presence in the service sector, especially gendersegregated activities, as well as in some new and growing industries such as electronics and information technology. Female-owned enterprises tend to face particular challenges in accessing some infrastructure services, such as the Internet, which is a critical cog towards success in international trade. They argue that, to a large extent, gender differences in terms of enterprise ownership could be explained by the challenges women face with regard to attitudes toward gender roles and stereotypes.

The trend globally is virtually the same. Recent surveys (Institute of Entrepreneurship Development 2016) show that gender differences still exist in the field of entrepreneurship. Despite the fact that women have been actively involved in the labour market in the past halfcentury, they still are disproportionately underrepresented as entrepreneurs. Their data shows that women are not playing active roles in business initiatives due to the many obstacles they face compared to men. Differences expressed in the survey include motivation, forms of business, reduced number of women who undertake business, attitudes of women in relation to men and personality of women in relation to that of men.

\section{Globalization and Gender Opportunities}

Globalisation is increasingly the order of the day, and women are an inherent part of this ever-dynamic system of international, economic and cultural flows (Lucas, 2007). With the mainstreaming of gender issues, women are now increasingly learning skills that were hitherto stereotyped as male related. Trade liberalization across borders has affected many small traders many of whom are women (World Economic Forum (WEF), 2013). The growth and diffusion of ICT related technologies in Africa over the past decade has been phenomenal. A significant proportion of this growth has been seen in mobile cellular phone technology which over the time has made cellphones more affordable and accessible for women. In addition to this, the diffusion of new information communication technologies 
(ICTs) and other emerging technologies have translated into more jobs and stronger connections to markets for many women, increasing their access to economic opportunities across many African countries (World Bank, 2012; African Union Commission, 2018).

When compared to the demographic growth patterns, the expectation would be that the main beneficiary and driver of these ICT trends are women, but this is hardly the case (Masika \& Bailur, 2015). In fact, ITU Statistics indicate that internet use across countries is often heavily skewed towards men (International Telecommunications Union (ITU), 2018). Nevertheless, trends towards more egalitarian gender roles and norms have also been accelerated and, in some cases, reinforced by women's economic empowerment.

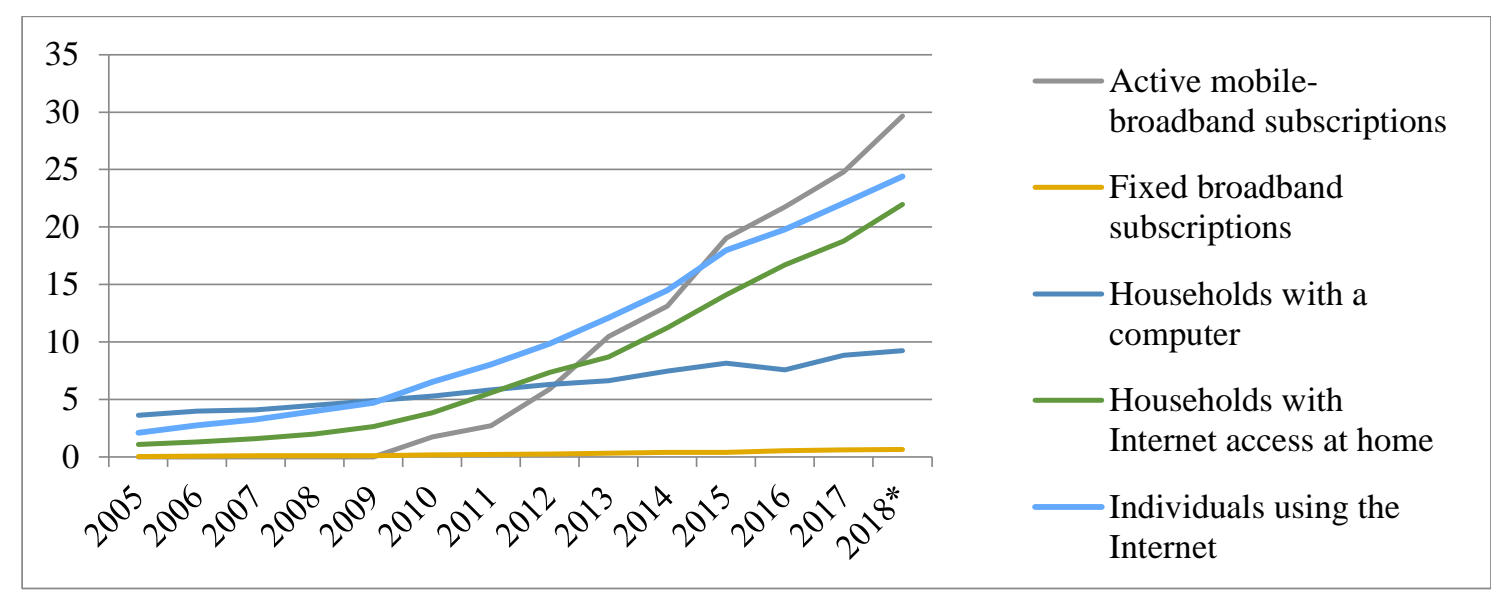

Figure 1: Trends of Key ICT Indicators in Africa- Penetration Rates per 100 Subscribers

Source: ITU World Telecommunications/ICT Indicators Database as at $30^{\text {th }}$ November 2018.

It has been argued that the increased access to information has exposed many women in Africa to information about life, economy, business opportunities and more importantly to issues affecting their business attitudes and behaviours thereby allowing them to transcend any socio-cultural and institutional limitations. This access has been propelled by IT-driven applications and software, for instance, social media applications/apps like WhatsApp, ecommerce platforms like OLX and other information based platforms. Extensive use of ICT allows specialized skills training. There are now more opportunities for M-commerce and Ecommerce at the informal economic levels which are mainly populated by women. This still notwithstanding, there are instances, whereby access to this new technologies have been limited due to men controlling women access within their respective households (Flestchner \& Kenney, 2011).

\section{Globalization and Gender Challenges}

Despite all the optimism indicated above and the concerted affirmative action across legal and political spheres, there are still challenges affecting women entrepreneurs. For instance, differences in education across genders have limited women's access to exports and new technological opportunities (Maigua, Maina, \& Ndegwa, 2017). These challenges are more pronounced in countries that have generally lower incomes and where there are socio-cultural limitations that affected the enrolment of education to females. In addition to this and due to lower levels of education, female producers experience more constraints in accessing 
international markets than male producers as was empirically demonstrated in Samoa and in Mozambique and other Sub-Saharan countries (World Bank, 2012). Due to institutional and market failures, female farmers and entrepreneurs across the African countries have less access to land for production and use of credit than their male counterparts. Commensurately, women's weaker property rights in land and limited access to productive inputs also constrain their capacity to benefit from trade exports as in the case of horticultural exports in Senegal and Kenya (World Bank, 2012). Across Africa, trade liberalization and export promotion in agriculture has largely benefited medium and large producers more than small producers where women are largely concentrated. In a number of cases, small holders who are mostly women have been directly affected by the elimination of agricultural subsidies and the reduction of agricultural extension services (Froham, 2018).

Cultural stereotyping exists, and information that comes by way of globalization will need to overcome the cultural hurdles affecting women entrepreneurs. There is a significant amount of empirical research that indicates a transmission of behavioural attitudes across generations of family women. For example, daughters are less likely to work outside the home if their mothers did not and if it is a cultural norm for women not to work. Similarly, sons are less likely to marry women who work outside the homes (World Bank, 2012). Closely tied to this are job opportunities that are stereotyped for women, such as service and education as compared to those that are predominantly favoured by men, such as construction.

\section{The Concept of Women Entrepreneurship in Africa}

There are many discourses on the role of women in entrepreneurship and many of them have followed the developed world's interpretations on the construct of women entrepreneurship. There has been a momentum in mainstreaming the issues of gender discrimination across the globe against the typical public stereotyping of women in developed countries that limit women's abilities to be leaders in their own right. It is estimated that the economic losses caused by gender discrimination in Africa and the Middle East alone amount to over US\$900 billion (Froham, 2018). Indeed, according to the World Economic Forum Global Gender Gap Index, if no remedial action is taken, it would take 219 years to close the current gap in women's economic participation and opportunities! Globalization increases African exposure to these stereotypes as well. In a global setting, the impact of this activism has been felt across the World, for instance, the global theme of "Orange the World: \#HearMeToo" Campaign that brought to the fore issues that pertain to workplace gender harassment and discrimination. Some of these stereotypes have biased inherent evaluation tools against women as was demonstrated by a study on venture capital funding that determined that women were consistently underfunded (Kanze, Hwang, Conley, \& Higgins, 2017). In as much as progress has been noted mainstreaming gender issues that allow economic empowerment in Africa, there are still some countries that have barriers against allowing women to access economic opportunities (African Union Commission, 2018). These barriers range from legal requirements that require women to seek their husband's permission to get jobs to prohibition of women from opening bank accounts, signing contracts, or even registering formal businesses.

Although entrepreneurship is not often defined on the basis of gender, Schumpeter (1961) moved from the general definition, that is, the making of a "new combination" of already 
existing materials and forces that entrepreneurship throws up as innovations, as opposed to inventions and that no one is an entrepreneur forever but only when he or she is actually doing the innovative activity to a more specific definition of women entrepreneurship as "women who innovate or adopt business actively."

For a long time, it was argued that the traits that were used to describe entrepreneurs, for instance, self-centered, internal locus of control, self-efficacious, mentally free, able to withstand opposition, strong personality, resolute, firm in temper were the same traits or temperaments that were stereotyped to describe masculinity (Ahl, 2006; Marchant, 2018). The misconception therefore was that feminine traits were hardly entrepreneurial... a view that has since caused the emergence of discourse in women entrepreneurship. (Orser \& Elliot, 2015) offer another feminist perspective to the definition of a women entrepreneur whom they define as an individual who applies feminist values and approaches through entrepreneurship, with the goal of improving the quality and wellbeing of life. Prior to obtaining concurrence on the discourse, there is a need to appreciate the historical context of the role of women in entrepreneurship and economic development in general (Akyeampong \& Fofack, 2012).

In Africa, women form the bulk of informal enterprises and are mostly driven into that form of enterprise by necessity. For example, survey data from Kenya show that 47.9 percent of formal enterprises were owned by men compared to 32.2 percent by women. On the other hand, more than 60 percent of the informal enterprises were women-owned and are largely unsustainable entrepreneurial activity (KNBS, 2016). This problem in Kenya is replicated throughout Africa as argued by (Campos \& Gassier, 2017) and across the world (Cabrera \& Mauricio, 2017; Global Entrepreneurship Monitor (GEM), 2017). Female participation in entrepreneurial activities is comparatively higher in Sub-Saharan Africa than in any other region and women-owned businesses significantly underperform those owned by men (OECD/European Union, 2017; Campos \& Gassier, 2017). This is reinforced by cultural practices that do not recognize women entrepreneurial activity as "work", a strategy that is meant to devalue women entrepreneurial activities as subordinate to the opposite gender's work, leading to persistent gender gaps in African entrepreneurial activities. Seventy percent (70\%) of the informal traders in Africa are women (Froham, 2018) and therefore this calls for enhanced support to these business regimes as opposed to the traditional stereotype of eliminating informal businesses. Women businesses are predisposed to be informal in nature due to their adverse operating environments and accompanying stereotypes that limit their formalisation (African Union Commission, 2018).

(Agyire-Tettey, Ackah, \& Asuman, 2018) assessed determinants of returns to male and female entrepreneurship in Ghana, Kenya and Uganda at selected quartiles along the distribution, as well as examined gender gaps in returns to entrepreneurship and factors contributing to these gaps. They established a gender bias against female entrepreneurship in the three countries, as unobserved characteristics largely responsible for the gender gaps in entrepreneurial returns even though these three countries rank highly in a United Nations report (UNESCO, 2017), Such omissions, although prevalent in most African countries, emanate from how women entrepreneurs are conceptualized largely as insignificant participants in economic activities. 
In Arab Africa, mostly referred to as MENA region where Islamic religion is predominant, (Bastian, Sidani, \& El Amine, 2018) established that there is a lack of theoretical foundations, where most studies pay more emphasis on macro level indicators, such as culture and religion, and very few studies around organizational level variables; a lack of studies that analyze female entrepreneurship within ethnic groups, or studies that "acknowledge the complex social, cultural and religious diversity of the region; and inattention to particular regional experiences (e.g. refugees crisis) and emerging trends (p. 14)".

Notwithstanding the efforts to adequately conceptualize women entrepreneurship, there are still glaring areas that require investigation. These include the reasons why women form less than $50 \%$ of the entrepreneurs' population in spite of being almost equal in number demographically? An empirical Spanish study by (Navarro \& Jimenez, 2016) shows that relational capital, social class, the geographic scope, and economic sector amongst other factors are important variables that may stimulate or restrain entrepreneurship in women entrepreneurs. There is also a need to identify adequate examples of phenomena of women entrepreneurship that could allow comparative advantages so as to broaden their economic impact (Holienka, Zuzana, \& Zuzana, 2016). Research on women entrepreneurship has been further narrowed down to the following six areas: physiognomies and incentives of women entrepreneurs; availability and limitations of start-up resources which include finances; managerial issues of women-owned firms which include family-business relationships; availability and impact of women business networks; and measurement of business performance and growth (Holienka, Zuzana, \& Zuzana, 2016). Literature review of women entrepreneurship in Africa indicates that studies often narrow down to the availability and limitations of start up resources of women entrepreneurs, giving a wide berth to the other areas.

Moreover, research on Women Entrepreneurship is often viewed from the "male perspective", and the risk of wrong inference is real. In fact, we as male authors do not rule out this perception in our analysis in this paper! The above sets of results need to be looked at against the structural inhibitions that affect the performance of women. (Du Rietz \& Henrekson, 2000) confirmed that in as much as women enterprises underperformed men enterprises, there was no direct correlation of the underperformance with gender once the structural inhibitions were addressed. Moreover, research has shown that there is a need to configure the constructs of various concepts with regard to women entrepreneurship (Adom \& Asare-Yeboah, 2016). On the basis of empirical evidence from Ghana, this study also identified that there were issues that could be empirically explored, thereby providing additional insights on female entrepreneurship in Sub-Saharan Africa.

It is also important that when designing measurement instruments, these inhibitors are considered, and in cases of behavioural scales, qualities that are considered to be "masculine" reconsidered rather than wholly adopted without realizing that they would directly be biased against women entrepreneurs (Ahl, 2006). In an empirical study across four countries of an Austrian-headquartered global firm, it was noticed that women considered their level of entrepreneurial orientation much lower than those of men, even though their job performance was not much different from the men's. Policy discussions and conclusions based on entrepreneurial orientation as constructed could therefore be inaccurate (Fellenhofer, Puumalained, \& Sjogren, 2016). 
One popular framework on conceptualization borrows heavily from the $5 \mathrm{M}$ framework that was developed by (Brush, de Bruin, \& Welter, 2009). In this construct, researchers needed to consider the five critical factors that affect women's ability to launch and grow ventures. These factors included, markets, money, management, motherhood and meso/macro environment, with the last two being additions to the earlier 3M framework. The framework laid the groundwork for further empirical research on women's entrepreneurship. This framework appreciated the entrenchment of social activities of women entrepreneurs and considered the compound levels of influence on their entrepreneurial actions. Brush et al. (2009) appreciated the needed to develop further research that are context specific in understanding women entrepreneurship.

\section{Re-conceptualizing Women entrepreneurship in Africa}

In spite of the many gender-related structural inhibitions, women's entrepreneurship in African countries represents an underutilized opportunity for job creation, economic growth and social cohesion that can be harnessed (Forde, 2013). The need for reconceptualization of women entrepreneurship in Africa is well documented (Akyeampong \& Fofack, 2012; Brush, de Bruin, \& Welter, 2009; Adom \& Asare-Yeboah, 2016). A recent literature review indicated that there has been more interest over the past thirty years in women ventures in the developed world than Africa (Cabrera \& Mauricio, 2017). On the other hand, there has been concerted effort over this period of time to have women venturing into business and indeed the proportion of women starting businesses as measured by the Total Entrepreneurial Activity (TEA) in Africa has been higher than the rest of the world (Global Entrepreneurship Monitor (GEM), 2017). The previous conceptual approach that was more biased towards the male entrepreneur resulted in minimal attention being paid to the female entrepreneur and their innovations. Astonishingly, there were a lot of "hidden entrepreneurs" who operate in the informal economy that is dominated by women that fell out of the scope of the many studies (Forde, 2013). Such studies should consider the social entrenchment, historical perspectives and cultural creativity of the female entrepreneurs. Through a series of interventions as articulated in African Union member obligations under the African Union Agenda 2063 and the Sustainable Development Goals150 (SDGs), a roadmap for the actualization and execution of these rights has been defined (UN Women, 2018). As a result of this, there has been mixed stories of success and failures in addressing some of the challenges (African Union Commission, 2018).

Although the focus of concern is on women in global enterprise in Africa, the perspective of the framework is that much of what happens to women entrepreneurs, and certainly what represents their global entrepreneurial experience, is shaped by their individual (Brush, de Bruin, \& Welter, 2009; Minitti, 2009) and global discourse (World Bank, 2012) on women, moderated by national and community perceptions (Summatavet \& Raudsaar, 2015). In a phenomenon that is widely gaining currency known as the Entrepreneurship paradox, it has been demonstrated that not all prescribed policy measures and entrepreneurial activities evenly support an entrepreneurship ecosystem in all countries (Lafuente, Acs, \& Szerb, 2018).

We are persuaded by the arguments of Holienka et al., 2016 that that firstly, opportunity- 
driven women entrepreneurship is positively affected pretty much in the Mclleland fashion by alertness to opportunities, self-confidence, knowing an entrepreneur who has recently started, and the perceived high social status of entrepreneurs, while it is negatively influenced by a fear of failure, age (and therefore lower propensity to take risk), and household income. Secondly, necessity-driven female entrepreneurship is significantly correlated to selfconfidence, knowing a recent entrepreneur, and perceived high social status of entrepreneurs, while it is inhibited by fear of failure, age (especially the older entrepreneurs), household income and education. Ironically, no significant effect of alertness to opportunities is anticipated by necessity-driven activity. It is however paradoxical that empirical data indicates that there are more women entrepreneurs in informal businesses (and possibly) necessity driven by nature that there are women who are in formal and therefore opportunity driven by nature. This demonstrates glaring gaps in either our understanding or the inferences in women entrepreneurship in Africa.

Indeed, in an empirical study that entailed a cross country comparison between Poland and South Africa, (Kot, Meyer, \& Broniszewska, 2016) established that the characteristics of women entrepreneurs in the two countries were largely different. These characteristic were grouped into individual, social and environmental factors. Their recommendation was that more similar studies need to be carried out across countries to establish which specific characteristics affected women entrepreneurs across the various countries.

The transition between formal and informal economy amongst women entrepreneurs has also not been well conceptualized. Empirical studies in the developing world indicate that whereas the formal sector employment has stagnated, informal sector employment has increased, indicating inadequately conceptualized motivation for informal businesses (Lock \& Smith, 2015). Indeed, the question to be addressed is whether the necessity entrepreneurs are in fact self-employed rather than opportunity seekers.

We present below a conceptual framework that brings together different arguments from the literature that supports a re-conceptualization of the role of women in entrepreneurship.

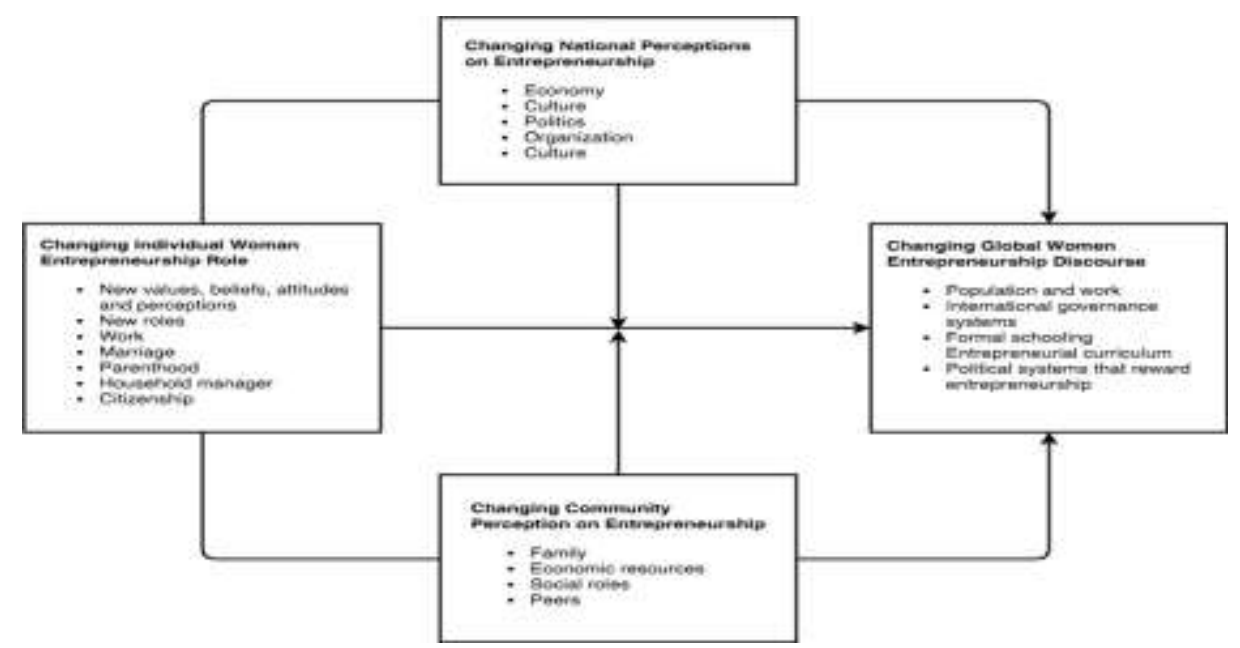

Figure 2: A Conceptual Framework for Changing Individual Women Entrepreneurship Role 


\section{Changing Individual perceptions}

Changing individual women entrepreneurship roles will take many dimensions such as redefining values, beliefs, attitudes and perceptions where society and women themselves can see themselves as any other individual in entrepreneurship rather than seeing themselves as women first. Other dimensions center around perceptions towards work, marriage, parenting, household management and citizenship. It is said that charity begins at home and so should equality too begin at home to eliminate the embeddedness of these chores in national and community perceptions. A disproportionate number of women come into entrepreneurship late in life mostly after child birth and this perhaps is a blessing where maturity can play a key role in reshaping the roles women play in the coming days. Further the changing demography offers a chance for a new thinking.

(Hunt, 2014), while analyzing Rwandese women, for example, argued that women "no longer confined to positions of influence in the home, they have become a force from the smallest village council to the highest echelons of national government. Understanding how and why such a transformation occurred offers not just an opportunity to celebrate their accomplishments, it also provides lessons for other countries struggling to overcome histories of patriarchy and oppression."

\section{Changing Community and National Perception Towards Women Entrepreneurs}

The perspective of the framework is such that what happens to women entrepreneurs constitutes their experience as moderated by national and community perceptions with respect to economy, culture, social, politics and organization as presented in (GithukuShongwe, 2017) to which their lives are embedded. On community, their experiences are moderated by family, economic resources, their peers and the social roles that define their distinctiveness as symbols of marginalization (Wolf \& Frese, 2018). Changing these deeply embedded practices is complicated but not insurmountable considering the fact that the population dynamics in developing countries could bring about the much needed women revolution.

\section{Changing the Global Discourse on Women and Entrepreneurship}

\section{Alternative Analytical Approaches}

The need to have alternative analytical approaches rather than replicating arguments that have been entrenched in developed backgrounds has been an ongoing discussion for the past two decades (Ahl, 2006) with no apparent significant convergence on the ideas. There is nevertheless an appreciation on that of entrepreneurship and more so when it affects women that requires to be viewed contextually (Lafuente, Acs, \& Szerb, 2018). Contextually, there is a need to review and appreciate the historical background of the role of the African woman in the economy and entrepreneurship in general (Akyeampong \& Fofack, 2012).

Is it time to re-think alternative analytical approaches that could give rise to a new understanding of globalization, entrepreneurship and gender equality in global commerce? The thought of looking for alternative analytic approaches is largely as a result of continued marginalization of women in spite of policy changes. 
Presently, the concept of women entrepreneurship conceptualized in Africa is based on the model of the more developed economies which structurally are based on information and data that are completely different and easy to access (OECD/European Union, 2017).

\section{Opportunity Exploitation and Entrepreneurship}

Can the current African conceptualization of women entrepreneurs lead to the exploitation of opportunities the emerging global order presents? We believe the inference will be wrong because the conceptualization is not accurate. The current conceptualization does not recognize the social behavioural aspects as well as the impact of change. Studies by (Arora, 2012) indicated that there was no conclusive linkage between structural reforms to achieve globalization and economic development across genders. This in effect is more pronounced across sub-national regions whereby disparities are evident and unfortunately, has not been exhaustively researched.

The effect of globalization, entrepreneurship and gender equality in commerce has seen mixed results. A cross sectional study in Africa by (Baliamoune-Lutz, 2006) showed that enhanced trade openness led to increased supply in unskilled labour leading to higher gender inequality. New opportunities require accompanying new skills and it is therefore imperative that if women are to benefit from these opportunities, then the level of education and skills retooling should always be considered. According to this study, there was no relationship between globalisation and gender equality in Africa. These findings were confirmed by (Arora, 2012) using data from India.

There is no doubt that tapping of women entrepreneurs creates a huge opportunity to further economic development. The major concern though is the pace of transformation. Recent studies have indicated that the key areas that require attention include a focus on human capital, stimulating an enhanced market demand and an enabling operating environment (International Finance Corporation (IFC), 2017).

The need for development of women entrepreneurship has been well articulated and there are many emerging opportunities to be exploited. Some of the areas that have received considerable attention include finance, entrepreneurial educational development and networking arrangements. In a recent analysis, (International Finance Corporation (IFC), 2017) identified several approaches to address the specific challenges. Interestingly, the study acknowledged that gender analysis often produced unexpected insights even though gender smart solutions were often mutually enforcing.

\section{Policy Implications}

This paper presents practical insights for policy makers to understand entrepreneurial gender inequalities in global commerce. (World Bank, 2012) noted that, "in the absence of public policy, globalization alone cannot and will not reduce gender inequality (p. 254)" . The review of literature has pointed out that there isn't much review that is done with respect with women entrepreneurs in the global commerce, and when it is done, it does not address the special consideration that is needed to respond to sustained discrimination of women in globalization in order to develop improved policies and practices that dominate the entrepreneurial landscape in Africa. Therefore, there is a need to understand how research can help create a better understanding of a situation that requires policy interventions that can lead to socio-cultural and economic changes that have greater impact on women 
entrepreneurship for Africa's economic progress. Several analytical dynamics are necessary, and they bring about a better gender sensitive analysis that can bring change. A new conceptual framework focusing on how individual changes to entrepreneurship roles can be implemented. The framework suggests that the influence of sustained global entrepreneurship discourse could necessitate change in national and community perceptions of woman's role in global enterprise to improve the individual woman's participation. There will be a need to create organizations that will champion deliberate programs to assist women entrepreneurs from the community level to the national level to participate in global entrepreneurship.

Policy considerations therefore require greater detail in order to deal with the biases that technically disenfranchise women from participating in global enterprises. (Vossenberg, 2013) suggested a series of guiding questions that would ensure that policies developed for women entrepreneurs are research driven and have an impact. These questions ranged from identifying the underlying reasons for the programme design, treatment of available data and knowledge, indicators and goals of the policies as well as a clear definition of the target group.

\section{Conclusion}

Although globalization brings new and unique opportunities for women, it also presents complex challenges that contradict established economic, organizational, political, social and cultural practices that are dominant in Africa. Gender inequality is still a major problem to the extent that it is not obvious to identify those types of inequalities that are accelerated by globalization and which are disrupted by globalization. Either way, the changing global narrative of the women's role in the modern world is impacting changes to individual women directly or through other intervening variables such as the changing national and community contexts. The Beijing Platform for Action, for example, provided the impetus that created awareness, monitoring and alleviation of the externalities that the new global system creates for women.

For advancing women entrepreneurship and globalization, gender inequality must be eliminated, but in order for this to happen, international organizations should intensify the change narrative and make it a national and community agenda that recognizes new roles for individual women. There is a glimmer of hope as more and more countries begin to recognize new roles of women leadership in society. The increased women labour participation has been noted to be closely correlated with economic growth in manufacturing and service sectors (Akyeampong \& Fofack, 2012). These leadership positions are more likely to increase the confidence of women in new roles, including entrepreneurship. Rwanda, as noted earlier, now has more women in leadership than in most countries across the world (Hunt, 2014). Ethiopia's new Prime Minister Abbey gave half of the ministerial positions to women (BBC Africa, 2018). Also, the political and legislative changes in the Kenya Constitution, enacted in 2010, require that at least one-third of all appointments be of women (Lock \& Smith, 2015).

Although there is a case for re-thinking of new alternatives, analytical approaches (Amine \& Staub, 2009), (Calas, Smircich, \& Bourne, 2009) to empower women entrepreneurs as a strategy to sustainably eliminate women inequalities may be counterproductive in Africa.

International Journal of Management \& Entrepreneurship Research, Ndemo \& Mkalama,, pp 89-104 Page 100 
Clair Holden (2019) makes a point on incremental changes for monumental gains for women entrepreneurs. Therefore, Africa's women entrepreneurs will do better with incremental changes rather than embracing methods of change that are confrontational. So far, educated women are breaking new grounds with respect to entrepreneurship. Sustained discourse on new roles of women in society and greater understanding of entrepreneurial opportunities will eventually lead to greater exploitation of those opportunities (Wolf \& Frese, 2018).

\section{References}

Adom, K., \& Asare-Yeboah, I. T. (2016). An Evaluation of Human Capital theory and Female Enterpreneurship in Sub Sharan Africa: Some Evidence from Ghana. International Journal of Gender and Enterpreneurship , 8 (4), 402-423.

African Union Commission. (2018). Women's Rights in Africa: Challenges, Opportunties and Proposals for Accelerated Implementation. African Union Commission, Department of Political Affairs. African Union.

Agyire-Tettey, F., Ackah, C. G., \& Asuman, D. (2018). Gender and Returns to Enterpreneurship in Africa. International Journal of Social Economics.

Ahl, H. (2006). Why Research on Women Entrepreneurs Needs New Directions. Entrepreneurship Theory and Practice , 30 (5), 595-621.

Akyeampong, E., \& Fofack, H. (2012). The Contribution of African Women to Economic Growth and Development in the Pre-Colonial and Colonial Periods: Historical Persepectives and Policy Implications. Policy Research Working Paper 6051, World Bank, Gender and Development Unit, Poverty Reduction and Economic Management Network.

Amine, L., \& Staub, K. (2009). Women Entrepreneurs in sub Saharan Africa: An Institutional Theory Analysis from a Social Marketing Point of View. Entrepreneurship \& Regional Development , 21 (2), 183-211.

Arora, R. U. (2012). Gender Inequality, Economic Development and Globalisation: A State Level Analysis of India. The Journal of Developing Areas , 46 (1).

Bahramitash, R., \& Esfahani, H. S. (2014). Gender and Entrepreneurship in Iran. Middle East Critique, 23 (3) , 293-312.

Baliamoune-Lutz, M. (2006). Globalisation and Gender: Is Africa Different? Journal of African Ecnomies , 16 (2), 301-348.

Bastian, L. B., Sidani, Y. M., \& El Amine, Y. (2018). Women Entrepreneurship in the Middle EAst and North Africa: A Review of Knowledge areas and Research Gaps. Gender in Management: An International Journal , 33 (1), 14-29.

BBC Africa. (2018). Ethiopia's Abiy gives half of ministerial posts to women. Retrieved from BBC Africa: https://www.bbc.com/news/world-africa-45881004

Brush, C., de Bruin, A., \& Welter, F. (2009). A Gender-aware Framework for women's enterpreneurship. International Journal of Gender and Entrepreneurship , 1 (1), 8-24.

Cabrera, E. M., \& Mauricio, D. (2017). Factors affecting the success of Women's Entrepreneurship: A Review Literature. International Journal of Gender and Entrepreneurship , 9 (1), 31-65. 
Calas, M., Smircich, L., \& Bourne, K. (2009). Extending the boundaries: reframing entrepreneurship as social change throough feminist perspectives. Academy of Management Review , 34 (3), 552-569.

Campos, F. M., \& Gassier, M. (2017). Gender and Enterprise Development in Sub Saharan Africa: A Review of Cosntraints and Effective Interventions. Policy Research Working Paper, WPS No.8239 . World Bank Group.

Du Rietz, A., \& Henrekson, M. (2000). Testing the Female Performance Hypothesis. Small Business Economics , 14 (1), 1-10.

Ernst and Young. (2011). Ambitious, Adept and agile. How global entrepreneurs are changing the world.

Fellenhofer, K., Puumalained, K., \& Sjogren, H. (2016). Entrepreneurial Orientation and Performance - are sexes equal? International Journal of Entrepreneurial Behaviour \& Research , 22 (3), 346-374.

Flestchner, D., \& Kenney, L. (2011). Rural Women's Access to Financial Services: Credit, Savings and Insurance. The Food and Agricultural Organisation of the United Nations, Agricultural Development Economics Division.

Forde, A. (2013). Female Entrepreneurship in a West AFrican Context: Network, Impoverisation and Dependency. Journal of International Women's Studies , 14 (3), 83-95.

Freeman, C. (2001). Is Local: Global as Feminine: Masculine? Rethinking the Gender of Globalisation. Signs , 26 (4), 1007-1037.

Froham, A. (2018, November 16). An Opportunity for a Gender Equality Focus in Trade Policy. Retrieved March 27, 2019, from International Centre for Trade and Sustainable Development: https://www.ictsd/org/opinion/an-opportunty-for-agender-equality-focus-in-trade-policy-in-trade-policy

Githuku-Shongwe, A. (2017). Changing the Game: Building Mindsets of Hopes and Possibilities in Africa's Future Leaders - One Game at a Time. In B. Ndemo, \& T. Weiss, Digital Kenya - An Entrepreneurial Revolution in the Making (pp. 85-93). London: Macmillan Publishers Limited.

Global Entrepreneurship Monitor (GEM). (2017). GEM Women Enterpreneurship 2016/2017 Report. Babson: Babson University.

Holden, C., (2019) Incremental Changes for Monumental Gains. Female Entrepreneur Collective. http://www.femaleentrepreneurcollective.com/incremental-changes-formonumental-gains/ [Accessed March 29, 2019].Holienka, M., Zuzana, J., \& Zuzana, K. (2016). Drivers of Women Entrepreneurship in Visegrad Countries: GEM Evidence. Procedia - Social and Behavioural Sciences , 220, 124-133.

Hunt, S. (2014). The Rise of Rwanda's Women. Retrieved from Foreign Affairs Magazine: https://www.foreignaffairs.com/articles/rwanda/2014/2014-03-30/rise-rwandaswomen

Institute of Entrepreneurship Development (2016) Statistics and Trends of Gender Equality and Entrepreneurship in Europe. https://ied.eu/project-updates/statistics-trendsgender-equality/ [Accessed March 29, 2019].

International Journal of Management \& Entrepreneurship Research, Ndemo \& Mkalama,, pp 89-104 Page 102 
International Finance Corporation (IFC). (2017). Investing in Women: New Evidence for the Business Case. Washington: IFC.

International Telecommunications Union (ITU). (2018). World Telecommunications/ICT Indicators Database USB Key. Retrieved January 2019, 17, from International Telecommunications Union: https://handle.itu.int/11.1002/pub/81074824-en

Kanze, D., Hwang, L., Conley, M. A., \& Higgins, E. (2017, June 27). Havard Business Review. Retrieved March 27, 2019, from Male and Female Entrepreneurs Get Asked Different Questions by VCs and it Affects How Much They Get: https://hbr.org/2017/06/male-and-female-entrepreneurs-get-asked-differentquestions-by-VCs-and-it-affects-how-much-funding-they-can-get

KNBS. (2016). Micro, Small and Medium Establishment (MSME) Survey: Basic Report. Kenya National Bureau of Statistics. GOK.

Kot, S., Meyer, N., \& Broniszewska, A. (2016). A Cross Country Comparison of the Characteristics of Polish and South African Women Enterprises. Economics and Sociology , 9 (4), 207-221.

Lafuente, E., Acs, Z., \& Szerb, L. (2018). The Entrepreneurship Paradox: More entrepreneurs are not always good for the economy - the role of the entrepreneurial ecosystem on economic performance in Africa. SSRN Working Paper Series.

Lindio-McGovern, \& Wallman. (2016). Globalization and Third World Women: Exploitation, Coping and Resistance. Routledge: Tailor and Francis Group.

Lock, R., \& Smith, H. L. (2015). The Impact of Female Entrepreneurship on Economic Grwoth in Kenya. Working Paper no.26, Birkbeck college, University of London, Centre for Innovation Management Research, London.

Lucas, L. (Ed.). (2007). Unpacking Globalisation: Markets, Gender and Work. Plymouth: Lexington Books.

Luis, A. D., Moore, E. M., \& Max, A. (2018). Female Entrepreneurship and International Organisations. (N. Apostolopoulos, H. Al-Dajani, D. Holt, P. Jones, \& R. Newbery, Eds.) Entrepreneurship and the Sustainable Development Goals , 8, pp. 165-183.

Maigua, J., Maina, L., \& Ndegwa, C. (2017, June 13). Challenges and Opportunities in Kenya Macadamia Nuts Industry: A Gender Perspective . Bridges Africa , 6 (14) . Geneva, Switzerland: International Centre for Trade and Sustainable Develoment (ICTSD).

Marchant, E. R. (2018). Anyone Anwhere: Narrating African Innovation in a Global Community of Practise. University of Pennsylvania.

Masika, R., \& Bailur, S. (2015). Negotiating Women's Agency through ICTs: A Comparative Study of Uganda and India. Gender, Technology and Development, 19 (1), 43-69.

Minitti, M. (2009). Gender Issues in Entrepreneurship. Foundations and Trends in Entrepreneurship , 5 (7-8), 497-621.

Navarro, J. P., \& Jimenez, A. M. (2016). Modern Elements of Entrepreneurship: Gender Differences. Suma de Negocios , 7, 47-53.

OECD/European Union. (2017). The Missing Entrepreneurs 2017: Policies for Inclusive Entrepreneurship. Centre for Entrepreneurship, SMEs, Local Development and Tourism. Paris: OECD Publishing.

International Journal of Management \& Entrepreneurship Research, Ndemo \& Mkalama,, pp 89-104 Page 103 
Orser, B., \& Elliot, C. (2015). Feminine Capital: Unlocking the Power of Women Entrepreneurs. Stanbford Business Books.

Osoro, K. M., Nyamongo, D., \& Areba, J. (2013). Constraints FAcing Women Entrepreneurs in Kenya: A Case Study of Micro and Small Enterprises in Kisii County. Journal of Humanities and Social Science, 16 (6).

Ratten, V., \& Tajeddini, K. (2018). Women's entrepreneurship and internationalization: patterns and trends. International Journal of Sociology and Social Policy , 38 (9/10), 780-793.

Stark, B. (2003). Women and Globalization: The Failure and Postmodern Possibilities of International Law. In N. Passas (Ed.), International Crimes. London: Routledge.

Subhalakshmi, G. (2012). Impact of Globalisation on Women Workers in India. Retrieved from Ernst and Young: http://www.impowr.org/journal/impact-globalization-womenworkersindia\#sthash.G91vWxwJ.dpuf

Summatavet, K., \& Raudsaar, M. (2015). Cultural Heritage and Entrepreneurship inspiration for novel ventures creation. Journal of Enterprising Communities: People and Places in the Global Economy , 9 (1), 31-44.

UN Women. (2018). Report and Recommendations from the Regional Consultations on SDGs Localization and Implementation in East and Southern Africa: Making Progress on Gender Equality and Women Empowerment - Progress on the Localisation of the Sutainable Development Goals (SDGs). UN Women, UNECA, UNDP. United Nations.

UNESCO. (2017). UNESCO and Gender Equality in Sub-Saharan Africa. UNESCO.

Vossenberg, S. (2013). Women Entrepreneurship Promotion in Developing Countries: What explains the gender gap in entrepreneurship and how to close it? Working Paper No. 2013/08, Mastricht School of Management.

Wolf, K., \& Frese, M. (2018). Why Husbands matter: Review of spousal influence on women entrepreneurship in sub-Sharan Africa. Africa Journal of Management , 4 (1), 1-32.

World Bank. (2012). Globalization's Impact on Gender Equality: What's Happened and What's Needed. World Development Report.

World Economic Forum (WEF). (2013). The Africa Competitiveness Report 2013. World Economic Forum, World Bank, Africa Development Bank, Ministry of Foeign Affairs of Denmark. World Economic Forum. 